\title{
The university as a terrain for hidden language conflicts? German, English and the silence beyond them
}

\begin{abstract}
In this paper, language policy (LP) at the University of Salzburg (Austria), a mid-size seemingly monolingual university, serves as an example to analyse (potential) language conflicts at the institutional level considering the roles played by German, English and 'immigrant' languages at the university. Language management, beliefs, and (reported) language use by different stakeholders in higher education (administrators, academic and administrative staff and students) are contrasted, also taking into consideration different linguistic backgrounds (German as L1, German as L2 and German as a foreign language). This offers an overall perspective on institutional LP that is still group sensitive, one that reveals two different hidden language conflicts: the non-addressed conflict between the two most important and visible languages at the university by far, German and English, as well as the neglected and negated conflict between German and the hidden "immigrant" languages. A consistent 'internationalisation at home' strategy would address these hidden conflicts and show backwash effects on ideas of language use in education as well as in society in general.
\end{abstract}

Keywords: language policy, language conflict, English as a lingua franca, immigrant languages, higher education

\section{Introduction}

The following paper deals with language policy (LP) at a mid-size university in an area of moderate linguistic diversity, Paris Lodron-University Salzburg (PLUS) (Austria). It aims to give an overview about the LP of PLUS with regard to the three components Spolsky (2009: 4) identifies for language policy, i.e. practices, beliefs and management.

Despite its focus on one single Austrian university, this chapter seeks to be exemplary of many universities that conceive of themselves as being rather 'monolingual' in their general appearance and their day-to-day affairs. Nevertheless, they also have to initiate and manage linguistic diversity as they attract international students and staff, introduce other languages, and strive to have both a broader international reach

\footnotetext{
Monika Dannerer, Institut für Germanistik, Universität Innsbruck, Innrain 52, A-6020 Innsbruck,
} Österreich, monika.dannerer@uibk.ac.at 
and a strong international reputation. Special attention is given to the way the university deals with 'local' multilinguals (or: language diversity that is not the result of academic mobility) and to the way these multilinguals perceive themselves in this environment. The main questions are whether the different L1s are used in different contexts or whether they are instead 'hidden languages' (Vogl 2012), and secondly whether there are overt or covert language conflicts about the roles of German, English and 'immigrant languages' in the language diversity management, beliefs and practices of the different stakeholders: administrators, academic and administrative staff, and students.

\section{The interrelation of language diversity management, beliefs and practices}

With its focus on the university, this chapter deals with LP on a meso level, but it also has to consider influences of the "wider sociolinguistic ecology" (Spolsky 2009: 30), thus at the micro and macro levels as well as at other educational institutions. The interrelation between management, beliefs and practices postulated by Spolsky (for an overview of LP definitions see e.g. Johnson 2013, Dorostkar 2014: 34-44; Darquennes 2013: 12) makes it necessary to have a close look at each of the components separately, but also to consider their reciprocal influences.

Both different university stakeholders and groups with different linguistic backgrounds can be assumed to display different practices, beliefs and management actions; therefore, I will treat them separately. This will allow for a clearer focus on competing and contradictory positions and thereby on the question of whether there are language conflicts and of how they are framed.

Language management occurs on different levels: While simple management can be even seen in self-corrections, organised management can express itself e. g. in regulations (also corrections) by parents, teachers or by government (Spolsky 2009: 12-13). The management of language diversity on an institutional level has to deal inter alia with the use and further development (or suppression) of languages and varieties that are brought into the institution and/or are supposed to be further acquired by different groups. Managing linguistic diversity seems to be important to all institutions with members who speak different languages, and indeed, these institutions seem to be the overwhelming majority.

Language management is clearly influenced by beliefs. Members of a speech community assign values to languages and varieties and have certain beliefs concerning the importance of these values. Beliefs as the cognitive component of attitudes may be interrelated with intensive affective reactions (Garrett 2010: 31) and may - in a more elaborated combination - form language ideologies, which are shared by certain community members (Spolsky 2012: 5). 
The third component of LP are practices as observable behaviour and choices. Spolsky concedes to them the highest relevance, as they serve as a model (Spolsky 2009: 4-6). They are influenced by language management without being simply determined by decisions 'from above', as well as by beliefs about languages, their values and ways of learning them.

The following section sketches the main concerns of management, beliefs and practices in language policies in HE and outlines both the different stakeholders and potential conflict lines.

\subsection{Management}

Yanaprasart/Lüdi (2018: 825) state that "Higher Education is caught between on the one hand internationalization, i. e. the need to compete in the international arena, and on the other hand the quest for local support by fostering the national languages, cultures and values." Most universities today therefore explicitly or implicitly focus on at least one of the following two domains of language management: One that concerns the availability of courses that allow incoming students (and staff) to improve their skills in the dominant national language(s) and/or one (pertaining essentially to universities in non-English-speaking regions) that concerns the role assigned to English as the dominant language of research and of internationalisation processes (including the offering of EFL classes or even regular classes, lectures or entire courses of study in English). ${ }^{1}$

For academic staff, language diversity management implies deciding which languages to use for presentations and publications (if the research field, the conference or journal offers such a choice at all), which languages to use and allow in classes and for student papers (in compliance with or in contrast to the regulations of the university), and which language and varieties to use and to allow for everyday interaction in meetings and casual exchanges. Both administrative staff and students can also take management decisions within specific contexts (types of interaction, settings and social groups).

\subsection{Beliefs}

For schools, Gogolin (1994) coined the expression of the 'monolingual habitus', which signals that despite the fact that many pupils are multilingual, the institution itself displays monolingual attitudes and beliefs in the way it conceives of itself, ignoring

1 For further concerns of universities in bilingual or multilingual regions, see various papers in this volume. 
the special needs of multilingual students and parents as well as the added value of the languages they bring. For universities this perspective can be broadened into the direction of a 'monolingual habitus plus English' (Dannerer/Mauser 2016) based on the "[...] widespread belief that international education equals the use of English as a medium of instruction and vice versa" (Mortensen 2014: 425). Even 'multilingual universities' are not emancipated from the 'monolingual mindset'. They too favour or construct hierarchies between languages or assign different domains to them (Weber/ Horner 2013).

In the realm of internationalisation, management decisions seem to be guided by three language-related beliefs, namely the belief that internationalisation almost automatically leads to linguistic pluralism, to intercultural understanding and to an improvement in scientific and educational quality (Fabricius et al. 2017). In the underlying discourse, two concepts are at odds: English is either favoured as the only solution or banned as a threat to the national standard language. All in all, these beliefs do not include the linguistic diversity that exists already even within a 'monolingual' country and within 'monolingual universities' due to the presence of large groups of students for whom (and/or for whose parents) the 'national' language is not the L1.

It is only recently that management decisions like the "internationalisation at home” strategy (cf. Soler/Gallego-Balsà 2019: 20-23) have begun to consider "a university's own domestic cultural, religious, and ethnic diversity as a resource” (Soler/ Gallego-Balsà 2019: 21). Whether these efforts are based on beliefs that go beyond what Kinsella et al. (2016: 3) criticise as "neoliberal understandings of the purely instrumental value of language at universities" deserves to be evaluated more closely.

\subsection{Practices}

Practices are influenced by language management measures without being simply their outcome. For example, the principle of 'parallel language use' at Nordic universities (e.g. Bolton/Kuteeva 2012; Mortensen 2014: 426) does not automatically evoke a "non-integrated use of Danish [or another local language, M.D.] and English at the institutional level" (Mortensen 2014: 426)². The same holds for pro-English language ideologies and norms of using English in interaction, as they do not necessarily result in an English-only practice (e.g. in student working groups) but in various different forms of using languages including situational differentiations (e.g. the local language for informal topics) or bilingual medium education (Mortensen 2014: 432-438; Ljosland 2014).

2 Cf. also the current language policy of the University of Oslo (https://www.uio.no/english/foremployees/support/profile/language/ [16. 05. 2020]) and the critical remarks by Weber/Horner (2013: 112f.). 
Different practices for moving from one academic language to another (e.g. van der Walt 2013), examples of codeswitching or translanguaging in university courses at bilingual or trilingual universities show positive outcomes. They enrich conceptual understanding, reveal hidden or implicit meanings, or defamiliarise familiar meanings (Veronesi/Spreafico 2009; Anderson et al. 2013; Mazak/Carroll 2017; and Yanaprasart/Lüdi 2018).

Still, little is known about language practices involving the use of immigrant languages and non-standard varieties of national languages (Dannerer/Mauser 2018) in academic contexts. Are they used? To which extent, with whom and in which situations? Are there (dis-)advantages for students' (and researchers') academic progress and for the administrative development of a university? Van der Walt (2013: 120) supposes that “[...] conscious and productive activation of other academic languages may be inhibited or suppressed either by the student or by a dominant and monolingual university culture, thereby (possibly) disadvantaging the student's academic progress." But there might also be unused potential for students and for academic and administrative staff. In recent projects Preece (2019) has also turned to this topic, differentiating between elite incoming students and working-class Black and Minority Ethnic (BME) undergraduate students, a perspective that more clearly highlights underlying conflicts (cf. 2.5).

\subsection{Groups}

When investigating LP at the university, it is necessary to distinguish the main groups and their practices, beliefs and methods of language management, i.e. students, academic staff and administrative staff. ${ }^{3}$

The perception of LP may also vary due to the individual linguistic, geopolitical and linguo-political background, thus 'local' members of the university community have to be distinguished from incoming academics and students. For universities like Salzburg that have not officially declared themselves to be bilingual or trilingual universities like Bolzano, Fribourg, Lleida and Luxembourg have, but instead understand themselves to be primarily 'monolingual', academics and students using the dominant national language as L1 have to be investigated separately from those with non-dominant L1s. This latter group consists of the highly desired incoming students, lecturers and researchers, who promise to bring with them the coveted 'internationalisation' but also of 'locals' who fail to fulfil some of the important characteristics of academic competition. As students, these 'locals' do not pay high fees, nor do they count toward university rankings, but instead speak German (too) and have completed

3 The role of the administrative staff is rarely documented (but e. g. Llurda et al. 2014; Dannerer in prep.). 
(at least some) schooling in Austria. They often do not speak the desired languages and may not even have mastered their L1 at an academic level. Nevertheless, their languages enlarge the linguistic repertoire of the university to a significant degree. The same holds true for administrative and academic staff.

\subsection{Potential conflicts}

As language contact is usually imbalanced according to the quantitative and qualitative importance of languages as well as their overt and covert prestige within the aims and social networks of the institutions, manifest or hidden language conflicts are to be expected. The focus in this paper is not on real language conflict (what Nelde [2000: 443-444] calls “"naturally evolved' or traditional conflicts”), but on institutional language conflict (in Nelde’s terminology ““artificial” or self-created conflicts”).

Such a perspective gains further importance, as in the context of language conflict research the focus on the institutional perspective is "still in its infancy" (Darquennes 2015: 11; but Ammon 2006).

Language conflicts about the role of languages/varieties in $\mathrm{HE}$ - the conflict about "what language has" (Darquennes 2018: 67) - can be expected to manifest themselves in two ways:

(a) the conflict between the national (standard) language and the use of academic English in research, teaching and administrative domains (e.g. Cots et al. 2012; Llurda et al. 2014: 378) - at a macro level perspective this is equivalent to the conflict between a national language and a "language of wider communication" (Dua 1996: 2f.).

(b) the conflict about the role of L1s other than the national (standard) language/ official language of the university and English (Dannerer/Mauser 2016). Incoming academics and students bring with them different languages, as do local students and local (non-)academic staff with their linguistic repertoires. They comprise not only languages learned at school (like French, Italian, Spanish and Russian), but also regional varieties as well as minority languages and languages of recent immigrants. All these languages come into contact when academic, didactic and administrative tasks are performed (as they surely do in social situations). The equivalent on the societal level would be the conflict between national/majority language and minority languages (Dua 1996: 2).

Two questions are of main interest in this context, which will be in the focus of this paper:

1) If there are (overt/covert) conflicts, how are they displayed? Do language management measures reveal conflicts in the way they are discussed or implemented? Do speakers signal conflicts in their beliefs, when they position themselves towards their repertoires? Do they explicitly or implicitly announce conflicts when they 
speak about their use of languages? Are there any hints of processes suppressing parts of linguistic repertoires - likely even at the risk of endangering the position of languages other than English in HE as Cenoz/Gorter (2012: 317) fear?

2) Which role do the different L1s play? Are they overtly presented and successfully used in fulfilling different tasks or are they hidden languages (cf. Vogl 2012; Dannerer 2018) or even hindrances for an academic career?

\section{Data and Methods}

The data for this chapter stem mainly from the project VAMUS ("Verknüpfte Analyse von Mehrsprachigkeiten am Beispiel der Universität Salzburg” / "Linked Analysis of Multilingualisms on the Example of the University of Salzburg”), which was conducted by Monika Dannerer and Peter Mauser. ${ }^{4}$ The project collected and interrelated data about language management, beliefs and practices of the main stakeholders, students, academic staff (teachers and researchers) and administrative staff at PLUS, as well as perspectives of university administrators (rector, vice rectors, deans, head of language centre) and the official language management documents of the university. A mixed methods approach was used to gain a multi-perspective, holistic overall view implying the qualitative and quantitative analysis of the following data (see Dannerer/ Mauser 2016 for more details):

- written documents (development plans of the university, statistical data and course catalogues) for a general overview of the existence of languages at PLUS and language management;

- 1,227 online questionnaires from students, academic and administrative staff with 33 to 47 mainly closed questions about their language competences (L1s as well as L2s and FLs), their use of languages and varieties in different situations (both private and academic), their beliefs about appropriate language use in academic contexts, about multilingualism in general and at the university, beliefs about and experiences with English for academic purposes, experiences of multilingualism as well as of discrimination due to the use of different languages and varieties etc.;

- 142 semi-structured interviews with the different stakeholders - deepening the insights of the questionnaires in language beliefs and reported language use;

- audio- or video-taped interaction in administrative and teaching settings for insights into language use.

4 The project ran from 2014-2018 and was funded by the Jubiläumsfonds of the Austrian National Bank (ÖNB Project No 15.827). 
Table 1: Overview Data

\begin{tabular}{|c|c|c|c|c|}
\hline & $\begin{array}{r}\text { Online- } \\
\text { questionnaires }\end{array}$ & $\begin{array}{r}\text { Interviews } \\
\text { (audio-taped) }\end{array}$ & $\begin{array}{r}\text { Language in interaction } \\
\text { (partially video-taped) }\end{array}$ & $\begin{array}{r}\text { Written } \\
\text { documents }\end{array}$ \\
\hline Students & 829 & 66 & diverse interactions & \\
\hline Academic staff & 197 & 36 & in teaching and & \\
\hline Administrative staff & 201 & 21 & administration & \\
\hline University administrators ${ }^{5}$ & & 19 & & 28 \\
\hline Sum & 1,227 & 142 & 19 & 28 \\
\hline Duration & & approx. $86 \mathrm{~h}$ & approx. $30 \mathrm{~h}$ & \\
\hline
\end{tabular}

The link to the online questionnaires was sent as an email to staff and students by the PLUS administration. A first call and a reminder motivated $5 \%$ of all students, $10 \%$ of the academic staff and $15 \%$ of the administrative staff to fill in the questionnaire. Based on their answers about the time and the context of the acquisition of German, we differentiated three target groups:

- mono-/multilinguals with German as L1 (“GL1”),

- multilinguals with German as L2, who finished schooling in a German-speaking area ("GL2"), and

- multilinguals with German as L2/foreign language (FL) who finished schooling in a non-German-speaking area (“GFL”) (cf. table 2).

Table 2: Subgroups and their distribution in online questionnaires

\begin{tabular}{lrrrrrrr}
\hline & Students & $\%$ & $\begin{array}{c}\text { Academic } \\
\text { Staff }\end{array}$ & $\%$ & $\begin{array}{c}\text { Adminis- } \\
\text { trative Staff }\end{array}$ & $\%$ & Sum \\
\hline German as L1 (= GL1) & 591 & 0,862 & 156 & 0,891 & 149 & 0,898 & 896 \\
\hline $\begin{array}{l}\text { German as L2, finished } \\
\text { schooling in a German- } \\
\text { speaking area (= GL2) }\end{array}$ & 33 & 0,048 & 3 & 0,017 & 6 & 0,036 & 42 \\
\hline $\begin{array}{l}\text { German as L2/FL, finished } \\
\text { schooling in a non-German- } \\
\text { speaking area (= GFL) }\end{array}$ & 62 & 0,090 & 16 & 0,091 & 11 & 0,066 & 89 \\
\hline \begin{tabular}{l} 
Sum \\
\hline
\end{tabular} & 686 & & 175 & & 166 & & $\mathbf{1 , 0 2 7}$ \\
\hline
\end{tabular}

5 The interviews with rectors, vice rectors, deans etc. were not only guided at PLUS, but also at the universities of Vienna, Innsbruck and the trilingual University of Bozen/Bolzano with the aim of broadening the insights of the perspective 'from above' and to see more clearly whether language management at PLUS is comparable to other universities in Austria or shows a special development. This contribution only refers to the results for Salzburg, although it became evident that Innsbruck and Vienna did not show substantial differences (Maier 2016). 
Persons who filled in the questionnaires could volunteer for the interviews. We interviewed all academic and administrative staff members who were willing to be interviewed. As numerous students wanted to participate in the interviews, we were able to select them in order to build a better-balanced corpus that was differentiated according to the groups named above (GL1, GL2, GFL) as well as to faculties and disciplines.

\section{Results}

As the number of international students that the university is able to attract serves as an important yardstick for 'internationalisation', universities proudly showcase data about the nationalities of their students. As a mid-size university (about 17,000 students in 2014), PLUS is situated in an area that borders Germany and has a student population that is about 65\% from Austria, 21.4\% from Germany, 1.5\% from (presumably German-speaking) Switzerland and from the Autonomous Province of South Tyrol, and 12.1\% from other countries (PLUS 2018: 101). As PLUS has no statistics about first languages of students, we can only guess that most of the students from 'other countries' belong to the GFL group.

In our online questionnaires, $9 \%$ of students belong to the GFL-group, making their frequency of participation slightly lower than their share as a percentage of the overall student body. On the other hand, there are only $4.8 \%$ of the students with GL2. If we consider that in 2013/2014 16\% of the pupils in secondary school spoke German as L2, ${ }^{6}$ this means that they are very weakly represented, be it in our corpus or at PLUS in general.

Academic staff with GL2 is even less represented (1.7\%); with GFL the percentage is significantly higher (9.1\%). For the administrative staff this difference is not as great (3.6\% vs. $6.6 \%) .{ }^{7}$ If we take these percentages as a reliable picture of the linguistic background at PLUS, we see a university whose members have mainly German as an L1 and one where people arriving after finishing school in their non-German L1 are much more frequent than bilinguals from the Austrian/German school system.

For the following analyses, I will start with a focus on language management and beliefs of university administrators - derived from written documents and their answers in the semi structured interviews - as language management from above can be supposed to frame the institutional context (4.1). This perspective will be contrasted with beliefs and reported use of German, English and other languages at PLUS,

6 Cf: http://www.schule-mehrsprachig.at/fileadmin/schule_mehrsprachig/redaktion/hintergrund info/info2-16-17.pdf, p. 24.

7 Like for PLUS there are no recent statistics about L1 in Austria, only about nationalities, indicating that in $201412.5 \%$ of Austrian inhabitants held a foreign passport (with a high percentage coming from Germany) (Statistik Austria 2020: 19). 
elicited in the questionnaires and interviews (4.2). In order to outline potential conflict lines, the perspectives are reported according to the time and the context of the acquisition of German as mentioned above (GL1, GLF, GL2). ${ }^{8}$

\subsection{Language management and beliefs from above}

As Austrian universities are not obliged to make an explicit language policy statement, different documents had to be scanned. Some statements could be found in the official development plan ${ }^{9}$ of PLUS. A comparison of these development plans from the last 10 years shows an interesting change towards a more explicit and more detailed language management concept.

The first mention dating back to 2009 is rather opaque. It presents the university as an institution that has to react to increasing outcomes of migration in such a way that it modifies course offerings or defines multilingualism as a starting point.

Eng verbunden mit den politischen, sozialen und kulturellen Transformationsprozessen sind demographische Veränderungen, die sich [...] darin manifestiert (sic!), dass es zu zunehmenden Auswirkungen der Migrationen kommt. Auch diesen Veränderungen werden die Universitäten Rechnung tragen müssen, sei es, dass sie ihre Lehrangebote entsprechend gestalten, sei es, dass sie Mehrsprachigkeit zur Voraussetzung machen. (PLUS 2009, 12; highlighting MD)

Demographic changes are closely related to the political, social and cultural processes of transformation, which manifest themselves in an increase in the effects of migration. Universities will have to react to these changes, either by designing their courses accordingly or by making multilingualism a requirement.

But multilingualism does not receive another mention in the document, nor is it clarified in which way and for whom PLUS makes multilingualism a point of departure (cf. Dannerer 2015).

Two development plans later (2016-2018), language management remarks are clearly oriented towards English, framed as the "lingua franca of today's academic community", which is promoted as a vehicle for an increasing internationalisation of PLUS designed to attract more incoming and outgoing students (cf. Dannerer 2018)..$^{10}$

8 The interactional perspective on language use cannot be covered here, but it would merit an extra chapter that includes different settings.

9 The development plan is an obligatory strategic planning instrument of Austrian universities, which are publicly financed yet autonomous in their planning. Based on the development plan, the Austrian Ministry of Education defines individual performance agreements ("Leistungsvereinbarungen") with each university. It has to focus on a three-year period with an outlook on the subsequent period.

10 Similar developments can be traced at other universities too, e. g. the University of Vienna (cf. Maier 2016: 96f.). 
The most recent development plan (2019-2024) is much more detailed on language management: The focus on internationalisation (the goal is to attract more incoming students) remains in combination with a focus on English. The plan mentions concrete goals such as more courses taught in English, and more master's and PhD programmes taught in English, more native speakers and more exchange networks with non-European English-speaking universities (PLUS 2018: 73, 97-103). Nevertheless, English competences and study abroad experiences are also seen as important for all students. In this context, multilingualism and intercultural experiences are mentioned as an asset for students' careers (PLUS 2018: 105) but are immediately reduced to English and the importance of the "internationalisation at home" strategy (PLUS 2018: 105). The development plan also shows a focus on supporting language competences among administrative staff, even promoting mobility programmes for them (PLUS 2018: 89-90; 106). It is only as part of this new twist that students from migrant families and students from ethnic minorities are mentioned as presumably benefitting from these measures, but without making clear how these advantages might look (PLUS 2018: 106). For the first time students from migrant families from Southeast European countries are seen as a pull factor for incoming students from this region (PLUS 2018: 102).

All in all, the role of languages/multilingualism is not particularly detailed, nor does it seem to be well integrated into other measures that are presented in these documents; nevertheless, PLUS does reveal an increasing focus on the use of languages in teaching and recently also in administration. There is no display of any conflicting interests, but there is an increasing belief that all interest groups will profit from a 'more English' strategy. This strategy has indeed been implemented. A comparison of the percentage of courses taught in English or in both German and English shows a clear increase between the 2014 and 2019 summer semesters: The percentage rose from $9.41 \%$ in 2014 to $11.29 \%$, whereas the percentage of courses taught in languages other than English or German fell from 3.83\% to $2.99 \%{ }^{11}$

In the interviews about language management strategies and beliefs of university administrators at PLUS and the other universities investigated in our project, the interviewees (i.e. rectors, vice rectors, deans and directors of university language centres) show similar attitudes and beliefs (Maier 2016: 169-173). All of them praise multilingualism; they appreciate linguistic diversity and laude it as a sign of a diversity of thinking, of equal opportunity and the result of a diversity of opinions. So does e.g. $\mathrm{S} 4^{12}$, in saying "im wesentlichen äußert sich denken und geist in sprache.

11 This overview does not include extracurricular language courses (e.g. at the university language centre) but does include language classes in philological studies as well as literature and linguistics courses in these disciplines). The percentage of courses outside of the philological studies was $9.69 \%$ for English and $0.87 \%$ for other languages in 2019.

12 In order to anonymize the members of this small group, they were labelled with the letter "S" for "Salzburg" and a randomized number as well as generally addressed using a feminine pronoun. 
und da kann die vielfalt ja nur ein gewinn sein"/ 'thinking and intellect express themselves predominantly in language; so diversity can only be an asset' (S4; cf. Maier 113).

However, when questions go a bit deeper, inconsistencies come to the surface: Administrators from backgrounds other than the natural sciences position themselves as rather critical toward an 'English only' policy that speaks about multilingualism but understands it as an intensified use of English.

$001 \quad$ S5: wir sehen [...], dass es notwendig ist, dass wir mehrsprachig sind.

002 wobei, ich muss auch hier wieder einschränken, dass wir englisch

003 sprechen [...] denn in der sozialwissenschaft is es ja mittlerweile so,

004 dass nichts anderes mehr zählt, das ist dann auch wieder der

005 pferdefuß [...] alles muss in englisch angesucht werden

$001 \quad$ we see that it is necessary that we be multilingual. but, I again have to

002 qualify that we speak English [...] because now in the social sciences

$003 \quad$ nothing else counts but English, that is a drawback [...]

004 every proposal has to be in English (S5; cf. Maier 116)

Nevertheless, all of the interviewees agree on the necessity of increasing the number of courses and entire study programmes in English. It is striking that nobody names complex or even adequate concepts that might support and develop multilingualism beyond English as the academic lingua franca. Conflicting ideas of a surplus through linguistic diversity and the stereotypical belief that English is the only solution for internationalisation become evident in the interviews.

\subsection{Language beliefs and reported language use from below}

\subsubsection{Perspectives of "monolinguals" (GL1)}

In all of the interviews and in the online questionnaires, the question of how multilingualism is seen in general is viewed in an extremely positive light. Students believe that multilingualism is important both for their subject and for their future career (4.1 on a scale from 1 [=do not agree] to 5 [=fully agree]). ${ }^{13}$ Nevertheless, more detailed questions relativize this answer.

Most of the monolinguals experience their university as being already 'rather multilingual' (Fig. 1), with quite sizeable differences between the groups and their

13 GFL students even show significantly higher ratings than GL1 and GL2 students (Vergeiner 2019: 161-162, 180). 
language preferences (or language skills). Students who answered the questionnaire in English (QuE) in particular but also academic staff with GL1 are less convinced than students who answered the questionnaire in German $(\mathrm{QuG})$ and administrative staff, who agree to a greater extent with this question (3.26 and 3.35):

“Is the University of Salzburg, in your experience, a multilingual institution?”

(1= no, not at all; 5 = yes, absolutely)

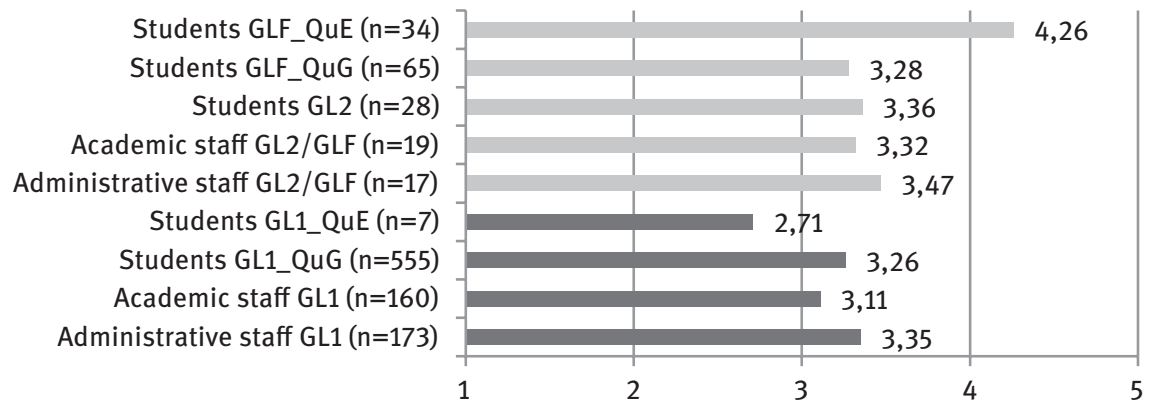

Fig. 1: PLUS as a multilingual university

Students with GFL who filled in the questionnaire in English give by far the highest approval rate (4.26) (see 2.4.2). In their answers to the question in which contexts multilingualism is experienced, it becomes evident that students come across multilingualism predominantly in private settings with other students, whereas academic staff members experience it most often with colleagues. Members of the administrative staff indicated that they encounter it in various situations (e.g. interaction with students and with other universities).

The opinions of students and academic staff about more English courses and degree programmes differ too (Fig. 2): Students want more degree programmes and more support when courses are given in English, whereas academics would like to make students read more texts in English. ${ }^{14}$

In the interviews, the question about the offering of whole degree programmes in English shows many more doubts. When the interviewer comes to the question of whether the students themselves would enrol in such a programme, most of the GL1 students would refuse. They don't see their language skills as adequate or they admit that they do not want to leave their comfort zone (SIF [GL1; communication science]: "bequemlichkeit”/'laziness'; SOK (GL1; Psychology): "zum anderen fühlt man sich in seiner muttersprache doch immer ein bisschen wohler"/'and on the other hand you

14 Other languages are only rarely desired: Both academic and administrative staff miss Romance languages in particular and - to lesser degree - Slavic languages (Dannerer 2017: 74; Dannerer i. prep.). 


$$
\begin{aligned}
& \text { Intensifying the role of English? } \\
& (1=\text { no, not at all; } 5=\text { yes, absolutely) }
\end{aligned}
$$

Should degree programs entirely taught in English be established?

Should there be more support by teachers?

Should students be required to read more texts in English?

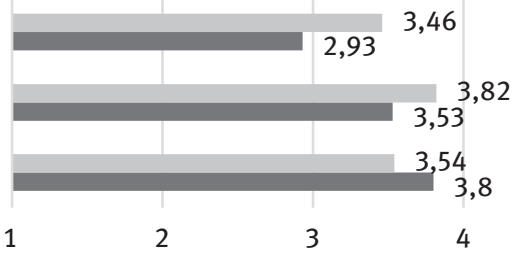

Students Academics

Fig. 2: Intensifying the role of English?

still feel more comfortable in your mother tongue'). Some of them think that it would not improve their job perspectives (e.g. as a future teacher: SUG [GL1; Teacher Training for Biology and Computer Science]: “die [die englischen Fachausdrücke; M.D.] brauch ich dann sowieso nicht, ich muss eh die deutschen können"/'I don't need them [the technical terms in English; M.D.] anyhow, I have to know them in German') and/or they fear having to acquire additional terminology in German.

The perspective of the PLUS academic staff in their interviews fits well with the perspective of these students: They are well aware of the fact that English presents them with a challenge. They report that many students have difficulty reading English texts or that they even avoid classes in English (LAG [GL1; communication science]: “da melden sich dann drei studierende an und sonst niemand"/'then three students enrol and nobody else'). Nevertheless, many teachers/researchers share the belief that English classes would be a step towards greater internationalisation. LUF for example argues that if the university wants to be international, it has to offer classes in English:

LUF (GL1; interfaculty department; total length: 30:30 min; extract: 25:02-25:08; 25:22-25:49)

001 IV: sehen sie im hinblick auf die äussere und innere mehrsprachigkeit

002 handlungsbedarf (.) von seiten der universität? [...]

003 LUF: ich denk, wenn man, wenn man sacht man? (-) legt wert drauf

004 irgendwie, international auch aufzutreten oder so? ${ }^{\circ} \mathrm{hh}$ dann gehören

005 da auch, äh öh lehrveranstaltungen, (-) speziell auf Englisch her.

006 andere sprachen sind da wurscht;=ja, die spielen überhaupt keine rolle.

007 IV: $\mathrm{mhm}$;

008 LUF: weil weil niemand irgendwie jetzt auf; aufäh- ${ }^{\circ} \mathrm{hh}$ äh 
$009 \quad$ (--) ja was soll ich sagen? (1.3) wenn ich jetzt irgendn beispiel

010 wähl, wär das natürlich diskriminierend aber? ${ }^{\circ} \mathrm{hh}$ (--) im prinzip is

011 englisch die einzige sprache die? (-) äh als gemeinsamer nenner

012 hergenommen werden kann.

001 IV: considering outer and inner multilingualism do you see

002 the necessity for the university to do something? [...]

003 LUF: I think when you when you say you attach importance

004 to appear international in some respects or so then you have to offer

005 also uh uh classes (-) especially in English.

006 other languages are irrelevant; yeah, they don't play any role.

007 IV: mhm;

008 LUF: because because nobody will somehow in; in uh- uh-

$009 \quad$ (--) hh yeah what should I say (1.3) if I chose an example

$010 \quad$ it would be discriminating but? in reality

$011 \quad$ English is the only language that (-) uh as a common denominator

012 can be used

LUF explicitly devaluates languages other than English (lines 6; 10-12), but the reason he gives (lines 8-10) shows the conflicting norms about the communicative values languages have: he struggles, gives metacommentary, pauses for 1.3 seconds and terminates with "in reality English is the only language that can be used as a common denominator”.

In general, the academic staff at PLUS tend to focus on the belief that multilingualism/the use of English facilitates international exchanges than on the opportunity to prepare local students for research as mentioned by Yanaprasart/Lüdi (2018: 829). Only very few teachers also favour languages other than English, judging them important for the future careers of their students (e. g. LAB [GL1; Psychology]: "in der psychologie ist es einfach so, dass es unglaublich wichtig ist, dass man therapeuten hat, die diese sprachen sprechen"/'in psychology it is just so important that you have therapists who speak these languages'). Multilingual language use is not commented on in detail. Nevertheless, the conflicting beliefs between the desire for English, the devaluation of other languages and the complaint about a lack of linguistic competences is also obvious in these interviews.

The perspectives for research are rather similar: German and English are by far the most dominant languages of publication at PLUS. Nevertheless, the staff also use 16 other languages, ranging from Bulgarian and Chinese to Hungarian and Turkish (cf. Dannerer 2015).

The position of the administrative staff is indeed highly pragmatic: In the interviews it becomes evident that they want to be supported in their desire to communicate 
“How do you see the role of multilingualism in your workplace?” $(n=201)$

( $1=$ no, not at all; $5=$ yes, absolutely)

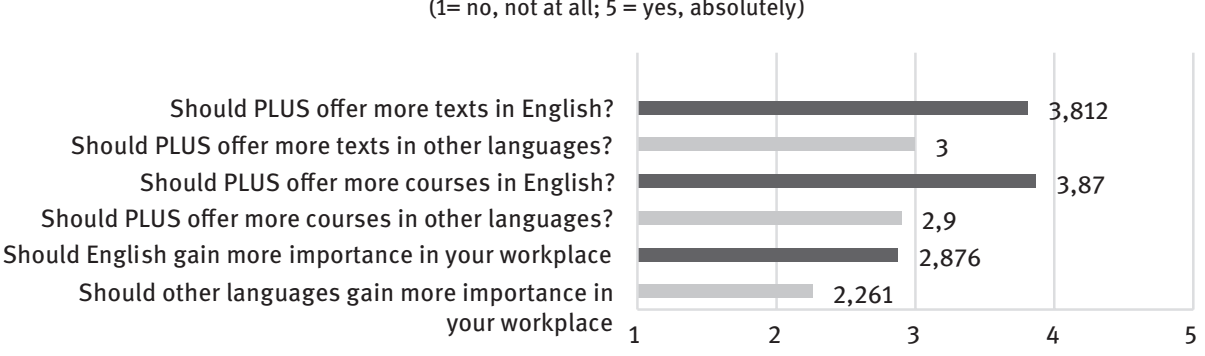

Fig. 3: Administrative staff about multilingualism in their workplace

smoothly; in the questionnaires they indicate that they would therefore like to have more forms, website pages, social media and especially language classes in English.

Languages other than English are not particularly desirable. Their LP credo is to use English whenever it is necessary and to switch to other languages whenever deemed advantageous (VAE: “je mehr barrieren abgebaut werden könnten, umso besser"/'the more barriers can be eliminated, the better'). They see themselves as facilitators without a language management agenda of their own (cf. Dannerer in prep.).

\subsubsection{The position of international students (GFL)}

International students display extremely diverse positions towards the roles of German, English and their first languages. In the interviews guided either in German or in English, it became clear that their attitudes depend on their first language, their language competences and their field of study. Their arguments for lectures and programmes in German are often local bound (e. g. SAB [GFL; History of Art; L1 Russian]: [es is] "nicht gerechtfertigt, wenn sie nach salzburg kommen, nach österreich, und deutsch nicht können"/ 'it is not justified when they come to Salzburg, to Austria and do not know German'): as they have come to an Austrian university, they expect courses in German. Many of them want to improve their German because they view it as important for their research and for their future careers (for similar results see Doiz et al. 2013 concerning the value of Spanish by exchange students at a university in the Basque Country). Voting for English is also combined with academic necessities and job perspectives (SIA [GFL; Law; L1 Slovene]: "in law it should be very important, for law german and french are two language that have to be known, english, german and french, but it is not enough said, it should be more, profs should encourage that more." $\left.{ }^{15}\right)$. Some of them see the PLUS as rather tolerant towards the use of non-German languages, and

15 The interview was conducted in English and has not been edited for grammar. 
gave examples for language management that encourages multilingualism (SEI [GFL; Law; L1 Slovene]: "the assistant [professor] is speaking so many foreign languages, so he gave opportunity to have presentation and ask question and write papers in all these different foreign languages too."). ${ }^{16}$ But the language management decision is clearly felt to be up to the teacher (or the curriculum) (SAG [GFL; Anthropology - Psychology; L1 Italian]: "its up me? no I don't think so, never (.) its up to me. ((laughs)) well uhm uh its its normal uh, to to speak the the same language as the uh as the teacher, if you can"). Only some of the interviewees vote for other languages: the neighbouring Slavic languages (for being able to interpret historical sources) or even Asian languages for geopolitical reasons.

In the arguments put forward in the interviews, they mix different perspectives: when they take their own perspective as a 'student from abroad', they speak overtly about the linguistic challenges of doing their studies in a foreign language. But they also stress the importance of this experience for their future job in or outside of academia (SOH [GFL; Law; L1 Czech]: "I think today it's important for every field of study. in every job you have to know foreign languages. [...] of course english and then at least one other language like german, french, spanish"). Their reflections also include what would be positive for other international students (to have courses in the language they know best) or for Austrian students (to face the challenge (SAD [GFL; European Union Studies; L1 Polish]: "lot of them study in english, but they do not want to communicate in english") and learn other languages or do (parts of) their studies in english or other languages).

The following chart (Fig. 4) is another example of how attitudes and answers differ according to L1 and language competences: International students with GFL who filled in the questionnaire in English ("QuE") were very keen about the idea of having more degree programmes taught entirely in English (4.00). Their peers who had the language skills to answer the questionnaire in German belong to the group that tended to reject this idea (2.69). In the interview they stress that they came to Austria for the sake of learning German. The students with GL2 are quite similar to the GL1 students (3.6 resp. 3.44). Those with GL1 who show a preference for the English by answering the questionnaire in English (GL1+QuE) vote for more degree programmes in English.

To sum up, for GFL students with a poor command of German, English is a necessity that really makes PLUS more attractive; for the others, both the programmes in German and the German-speaking world outside the university are the reason they have chosen PLUS. For "internationalisation at home" a minority of students is eagerly awaiting English-taught programmes; the others are rather sceptical.

16 This might be the reason why this group rated PLUS as a clearly multilingual institution. 
"Should degree programmes taught entirely in English be established?"

(1= no, not at all; $5=$ yes, absolutely)

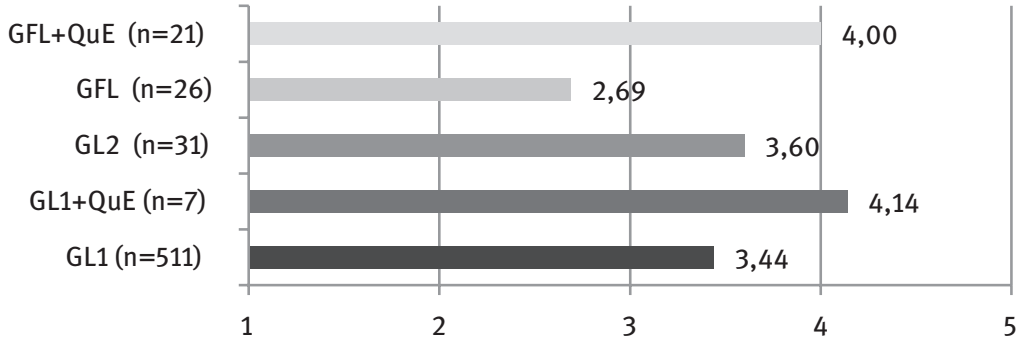

Fig. 4: Different groups of students about degree programmes in English

\subsubsection{The GL2 perspective: disregard of the parts of the repertoires beyond German and English}

The interviews show that multilingual students who finished school in a German-speaking country are seen by the academic staff as being at a more or less linguistically sufficient level. If problems arise, they occur in writing rather than in speaking. The additional languages these students speak are often unknown to their teachers, as is the fact that they are bilingual. Only some of the academic staff mention the importance of their students' languages for future jobs (law, psychotherapy, teaching) (see above). But during their studies these languages are not seen as important because they are not judged as relevant in research, nor are they taught at PLUS:

\section{LEF (GL2; Theology; total length: 56:56 min; extract: 43:55-44:37)}

001 LEF: kann ich mir nich vorstellen wie? (---) muss ich ehrlich sagen; (2.5) mh ich weiss es nicht;

002 ich ich sehs nich ein. (2.5) weil sie sie haben nichts direkt mit der wissenschaft zu tun.

001 LEF: I cannot imagine how? (---) I have to say honestly; (2.5) mh I do not know;

002 I I don't accept it. (2.5) because they they don't have anything to do with scholarship.

LEF hesitates twice but he cannot imagine an argument that does not take an instrumental point of view: immigrant languages have no relevance for scholarship (in Austria) - but should be used in private contexts.

The students from a GL2 background share these viewpoints. In their questionnaires, they stated that their L1 does not play an important role (1.55), but they did not 
GL2 students about L1, experienced and expected (dis)advantages ( $n=34)$

( $1=$ no, not at all; $5=$ yes, absolutely)

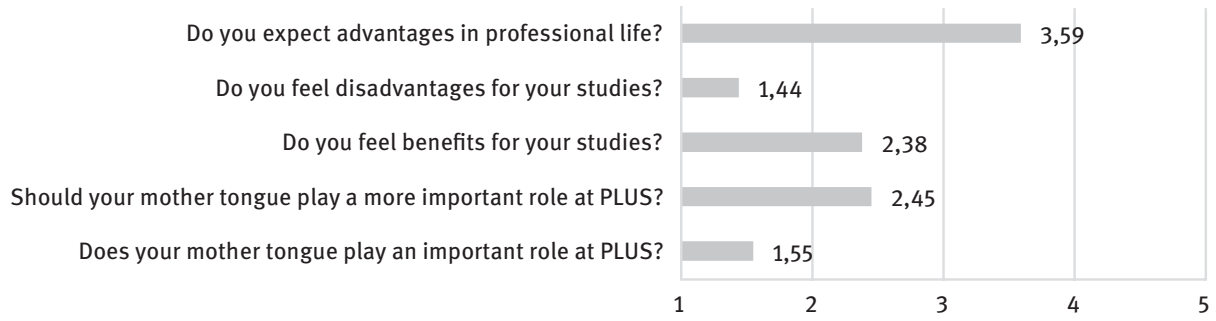

Fig. 5: Role of L1, experienced and expected (dis)advantages (Students, $n=34$ )

wish very strongly to change this situation (2.45) (cf. Dannerer 2017). Nevertheless, they expect their L1 to have positive effects on their future career (3.59).

In the interviews, their beliefs are similar: their language has no relevance (SAM [GL2; Law and Economy; L1 Turkish]: "meine muttersprache ist türkisch. und ich wüsste nicht, wie ich das auf der uni anwenden sollte"/'my mother tongue is Turkish, and I do not know how I could use it at the university'). It would only have value for them if they could make use of it on the job (SAH [GL2; Psychology; L1 Russian]: "mein vokabular ist auf der ebene einer achtjährigen, ich kann mich unterhalten, über alltägliche dinge, aber nicht über konkrete störungen"/'my vocabulary is at the level of an eight-year-old, I can communicate about daily topics but not about concrete disorders') or at universities in other regional/national contexts (in Croatia, in Turkey, near the border to the Netherlands).

They report language management that restricts them to German or English (SOD [GL2; Pedagogy; L1 Spanish]: “in meinem fall spanischsprachige oder anderssprachige literatur ist schwer, dass die zugelassen wird, auch wenn sie wissenschaftlich ist, weil sie nicht verstanden wird [...] es steht nirgendwo drinnen, es heißt nicht, man darf es nicht verwenden, aber lieber ist es, wenn es nicht verwendet wird“/ in my case Spanish or other literature, it would be difficult for it to be accepted, even when it is scholarly, because it is not understood [...] it is not written down anywhere, it is not said that you cannot use it, but it is better that you do not').

The picture for GL2 administrative staff is slightly different: Although they do not feel that their language is considered to be of great importance at the university, they believe that their L1 brings about moderate advantages in their job (3.38 points out of 5). In the interviews many of them display pride in their multilingualism and are glad when they can use their L1 to fulfil administrative tasks (VUC: "wenn studenten kommen, benutz ich das auch gerne"/'I like to use it [Romanian], when students come'). Nevertheless, they do not feel offended by the experience that English is the most important language. 


\section{Discussion and conclusions}

The analysis showed no open conflicts in the sense of vivid discussions or stringent positioning of the different groups. Nevertheless, there are hidden conflicts of a very different kind: On the one hand, we can see a conflict that is widely felt - except for research in the natural sciences - but not openly addressed, one between the national language and the lingua franca English (used as a "Language of Wider Communication" - LWC; Dua 1996). On the other hand, there are conflict lines between the national language as majority language and different L1s ('immigrant languages') as hidden minority languages. This conflict tends to be neglected or even negated. Both conflicts are mirrored in the components of LP of PLUS and are closely related to the broader linguistic and institutional environment.

\subsection{The hidden conflict between German and ELF - the case of a conflict that is not openly addressed}

Our data showed that PLUS is only about to initiate an active and precisely planned language management programme. The current 'laissez faire' principle strengthens the dominant role German plays in general in the Austrian education system as well as in Austrian society at large. It has broadened only in the course of the last five years towards strengthening the role of English as an academic lingua franca, considering its key position for research worldwide and its relevance for many academic jobs. PLUS is trying to improve English competences in administration and intensify English courses and degree programmes under the label of 'internationalisation' to attract incoming students and staff. Spontaneous language management at the course level and in the administration allows for the use of English.

Beliefs and reported language use do not just reinforce this path but are also sceptical or openly opposed. 'English only' is seen as a threat to the role of German as an academic language, to the quality of teaching and learning, and to a (potentially) multilingual language use. Laziness and a lack of language skills and habits are a hurdle for 'internationalisation at home' and the integration of English-speaking incoming students.

The conflict lines go across the different groups. Academic staff and students as well as GL1, GL2 and GFL are not homogenous: In general students are more open to English-taught degree programmes but want to have more support to be successful in their studies. Incoming students find it comfortable to choose between German and English, but when they already possess basic German skills, they aim to improve them and are not interested in English-taught programmes. Academic staff and students show an instrumentalist approach toward their subject and future job perspectives. Natural sciences are more open to a pro-English language management and tend not to see any negative side effects. But also for those 
who oppose 'Englishization' (Lanvers/Hultgren 2018) ELF is 'the only common denominator'.

Everybody seems to be aware of this topic, which in some facets is also of public interest, discussing the 'threats' of English to the German language e. g. by addressing the role of English borrowings (cf. e.g. Spitzmüller 2005). Despite its general importance, there is seemingly no open conflict nor a common discussion about the role of English and the relationship between German and English at PLUS, nor is there a concise concept of language management that takes into consideration the specific needs of the different stakeholders and groups at PLUS, the different scientific disciplines and the career profiles the graduates strive for. English is overtly present at PLUS as a language of research, teaching and administration, but the roles the two languages play as well as the weight that is given to them are the source of a hitherto avoided and therefore postponed conflict.

\subsection{The hidden conflict between 'immigrant languages' and German as well as English - a neglected and negated conflict}

The official language management measures of PLUS once showed fine traces of considering multilingualism through migration (PLUS 2009) but have left this path so that for the moment significant measures to support and improve other language competences are not apparent, nor do they seem to be highly desired by the stakeholders. Questions about the integration of immigrant languages in the classroom often provoke quite helpless reactions. Nevertheless, spontaneous language management by academic and administrative staff seems to be guided by individually established principles and individual language skills. Thus, the use of these languages can be hazardous and spontaneous. They play a certain role for publications related to a subject or to individual competences and research networks.

Despite such experiences, beliefs do not predominantly support languages other than German or English as being important to (future) professional and/or scholarly careers. Multilinguals with GL2 instead share the opinion that their languages will be important for their careers but are 'useless' in HE and therefore deserve neither further awareness nor support. The instrumental value attributed to language is oriented towards direct effects for research, job perspectives and interaction in administrative contexts. PLUS utilises individual bi-/multilingualism without systematically further developing it (cf. Cenoz/Gorter 2012: 316). The other groups (GL1, GFL) seemed not to be concerned at all. These beliefs mirror the prestige of many 'immigrant' languages as well as the 'monolingual habitus plus English' (Dannerer/Mauser 2016). We can speak of a neglected conflict, as many interviewees seem to fail to even recognise it and it does not occur in the written documents. This position might be seen as the result of a LP that marginalises these languages to an increasing extent as pupils 
move from primary to secondary school, so that they end up becoming completely hidden languages in HE. The interviews showed that this conflict is also negated when 'immigrant' languages are stigmatised as unimportant and irrelevant in HE in a 'German-speaking environment'. The GL2 group shows moderate but not open 'language discontent' (Du Plessis 2013) that might be anchored and echoed in many other domains of society.

Both conflicts at the institutional level mirror language conflicts in society in general and by far not just in Austria: Speakers of the national language (German) feel threatened by a LWC, a language of wider communication (English), and overrule minority languages. PLUS does not seem to regard the two conflicts as vital or urgent for the moment and they have therefore not been broadly discussed up to now.

If the university is interested in an internationalisation strategy that takes 'internationalisation at home' as a serious social task and not only as a form of self-positioning at the marketplace of $\mathrm{HE}$, then its rather homogenous situation would be an asset to developing forms of supporting multilingual practices. This would allow for the further development of L1 competences at an academic and professional level at the university. Finally, it would have a backwash effect on ideas of a more balanced use of languages in education and in society in general, and would prevent the hidden conflicts from turning into open discontent.

Acknowledgements: I would like to thank the reviewers for their careful readings of the first drafts of this article and for their valuable comments, which helped to sharpen the ideas I have expressed here.

\section{References}

Ammon, Ulrich (2006): Language conflicts in the European Union. In: International Journal of Applied Linguistics 16, 3, 319-338.

Andersson, Ingrid/Kagwesage, Anne Marie/Rusanganwa, Joseph (2013): Negotiating meaning in multilingual group work: a case study of higher education in Rwanda. In: International Journal of Bilingual Education and Bilingualism 16, 4, 436-450.

Bolton, Kingsley/Kuteeva, Maria (2012): English as an academic language at a Swedish university: parallel language use and the 'threat' of English. In: Journal of Multilingual and Multicultural Development 33, 5, 429-447.

Cenoz, Jasone/Gorter, Durk (2012): Language policy in education: additional languages. In: Spolsky, Bernard (ed.): The Cambridge handbook of language policy. Cambridge: CUP, 301-320.

Cots, Josep M./Lasagabaster, David/Garrett, Peter (2012): Multilingual policies and practices of universities in three bilingual regions in Europe. In: International Journal of the Sociology of Language 216, 7-32.

Dannerer, Monika (2015): Gewünschte, gelebte und verdeckte Mehrsprachigkeit an der Universität. In: ÖDaF-Mitteilungen 2/2015, 143-150.

Dannerer, Monika (2017): Sprachliche Repertoires an der Universität. Sprachliche Vielfalt und Einstellungen zu Mehrsprachigkeit an der Universität Salzburg. In: ÖDaF-Mitteilungen 1/2017, 63-75. 
Dannerer, Monika (2018): Mehrsprachigkeit als Programm - Mehrsprachigkeit wider Willen? Universitäre Mehrsprachigkeit zwischen Verpflichtung und Unwissenheit. In: Dannerer, Monika/Mauser, Peter (eds.): Formen der Mehrsprachigkeit in sekundären und tertiären Bildungskontexten. Verwendung, Rolle und Wahrnehmung von Sprachen und Varietäten. Tübingen: Stauffenburg, 421-440.

Dannerer, Monika (in prep.): Arbeitsplatz Universität - Mehrsprachige Repertoires und zweisprachige Praktiken? Spracheinstellungen und Sprachgebrauch vor dem Hintergrund universitärer Sprachenpolitik.

Dannerer, Monika/Mauser, Peter (2016): Österreichische Universitäten als mehrsprachige Interaktionsräume? Universitäre Sprachenpolitik vor dem Hintergrund des Projektes „Verknüpfte Analyse von Mehrsprachigkeiten am Beispiel der Universität Salzburg (VAMUS)“. In: Jablkowska, Joanna et al. (eds.): Literatur, Sprache und Institution (= Stimulus 23 Mitteilungen der Österreichischen Gesellschaft für Germanistik 2014). Wien: Präsens, 170-183.

Darquennes, Jeroen (2015): Language conflict research: a state of the art. In: International Journal of the Sociology of Language 235, 7-32.

Darquennes, Jeroen (2018): Language conflict research: a synopsis and some ideas on how to advance it. In: Jahr, Ernst Hakon (ed.): Perspectives on two centuries of Norwegian language planning and policy: Theoretical implications and lessons learnt (=Acta Academiae Regiae Gustavi Adolphi CLII; Vol. 152), Uppsala: Kungl. Gustav Adolfs Akademien för svensk folkkultur, 63-77.

Doiz, Aintzane/Lasagabaster, David/Sierra, Juan (2013): Globalisation, internationalization, multilingualism and linguistic strains in higher education. In: Studies in Higher Education 38, 9, 1407-1421.

Dorostkar, Niku (2014): (Mehr-)Sprachigkeit und Lingualismus. Die diskursive Konstruktion von Sprache im Kontext nationaler und supranationaler Sprachenpolitik am Beispiel Österreichs. Göttingen: V\&R unipress/Vienna University Press.

Du Plessis, Theodorus (2013): Language conflict and change in language visibility in South Africa's Free State Province number plate case. In: Language Matters 44, 3, 126-148.

Dua, Hans R. (1996): The politics of language conflict: Implications for language planning and political theory. In: Language Problems and Language Planning 20, 1, 1-17.

Fabricius, Anne H./Mortensen, Janus/Haberland, Hartmut (2017): The lure of internationalization: paradoxical discourses of transnational student mobility, linguistic diversity and cross-cultural exchange. In: Higher Education 73, 4, 577-595.

Garrett, Peter (2010): Attitudes to language. Cambridge: Cambridge University Press.

Gogolin, Ingrid (1994): Der monolinguale Habitus der multilingualen Schule. Münster: Waxmann.

Kinsella, Benjamin/Arpacik, Demet/Cioè-Peña, María (eds.) (2016): Editors' notes. In: Bellaterra Journal of Teaching \& Learning Language \& Literature 9, 2, 1-5.

Lanvers, Ursula/Hultgren, Anna Kristina (2018): The Englishization of European education. In: European Journal of Language Policy 10, 1, 1-11.

Ljosland, Ragnhild (2014): Language planning confronted by everyday communication in the international university: the Norwegian case. In: Journal of Multilingual and Multicultural Development 35, 4, 392-405.

Maier, Sebastian (2016): Universitäre Sprachenpolitik. Die Universitäten Salzburg, Innsbruck, Wien und Bozen im Umgang mit Formen der Mehrsprachigkeit. Unveröffentlichte Masterarbeit, Universität Salzburg.

Mazak, Catherine M./Carroll, Kevin S (eds.) (2017): Translanguaging in higher education. Beyond monolingual Ideologies. Bristol: Multilingual Matters.

Mortensen, Janus (2014) Language policy from below: language choice in student project groups in a multilingual university setting. In: Journal of Multilingual and Multicultural Development 35 , 4, 425-442. 
Nelde, Peter (2000): Prerequisites for a new European language policy. In: Journal of Multilingual and Multicultural Development 21, 5, 442-450.

PLUS (=Universität Salzburg) (2009): Entwicklungsplan der Paris-Lodron-Universität Salzburg 2009-2012. http://www.uni-salzburg.at/index.php?id=44834 [20.05. 2020]

PLUS (=Universität Salzburg) (2015): Entwicklungsplan der Universität Salzburg 2016-2018. http://www.uni-salzburg.at/fileadmin/multimedia/Die\%20Universitaet/documents/

Entwicklungsplan16-18.pdf Version 1, veröff. am 6. 5. 2015 [20. 05. 2020]

PLUS (=Universität Salzburg) (2018): Entwicklungsplan 2019-2024 Paris-Lodron-Universität Salzburg, Version 2. https://www.uni-salzburg.at/fileadmin/multimedia/ Qualitaetsmanagement/documents/Entwicklungsplan_der_Universita\%CC\%88t_ Salzburg_2019-2024_Version_2.pdf [20.05. 2020]

Preece, Siân (2019): Elite bilingual identities in higher education in the Anglophone world: the stratification of linguistic diversity and reproduction of socio-economic inequalities in the multilingual student population. In: Journal of Multilingual and Multicultural Development 40, 5, 404-420.

Soler, Josep/Gallego-Balsà, Lídia (2019): The sociolinguistics of higher education. Language policy and internationalisation in Catalonia. Cham: Palgrave Macmillan.

Spitzmüller, Jürgen (2005): Metasprachdiskurse: Einstellungen zu Anglizismen und ihre wissenschaftliche Rezeption. Berlin [u. a.]: de Gruyter.

Spolsky, Bernard (2009): Language management. Cambridge: Cambridge University Press.

van der Walt, Christa (2013): Active biliteracy? Students taking decisions about using languages for academic purposes. In: Haberland, Hartmut et al. (eds): Language alternation, language choice and language encounter in international tertiary education. Dordrecht: Springer Netherlands, 103-122.

Veronesi, Daniela/Spreafico, Lorenzo (2009): Between mono- and multilingualism in the classroom: communicative practices in a trilingual university. In: Proceedings of the International Festschrift Symposium for Paul N. Mbangwana: Language, Literature and Nation Building, Yaoundé, 199-235.

Vogl, Ulrike (2012): Multilingualism in a standard language culture. In: Hüning, Matthias/Vogl, Ulrike/Moliner, Olivier (eds.): Standard Languages and Multilingualism. Amsterdam: Philadelphia, 1-42.

Weber, Jean-Jacques/Horner Kristine (2013): Multilingual universities and the monolingual mindset. In: de Saint-Georges, Ingrid/Weber, Jean-Jacques (eds.): Multilingualism and multimodality. The future of education research. Rotterdam: SensePublishers, 101-116.

Yanaprasart, Patchareerat (2016): The challenge of the management of diversity. In: Lüdi, Georges/ Höchle Meier, Katharina/Yanaprasart, Patchareerat (eds.): Managing plurilingual and intercultural practices in the workplace. The case of multilingual Switzerland. Amsterdam: John Benjamins, 187-234.

Yanaprasart, Patchareerat/Lüdi, Georges (2018): Diversity and multilingual challenges in academic settings. In: International Journal of Bilingual Education and Bilingualism 21, 7, 825-840. 